\title{
Exploration of Double Tutorial System for Professional Master Degrees
}

\author{
He Jiang \\ School of Information \\ Qilu University of Technology \\ Jinan, 250353, China \\ jianghe09@126.com
}

\author{
Hongjun $\mathrm{Yu}$ \\ School of Information \\ Qilu University of Technology \\ Jinan, 250353, \\ China1103444721@qq.com
}

\author{
Yushui Geng \\ Department of Graduate \\ Qilu University of Technology \\ Jinan, 250353, China \\ gys@qlu.edu.cn
}

\begin{abstract}
Most universities use a form of "double tutorial system" to guide full-time professional degree postgraduates in China. Quality of on-campus and off-campus tutors is a key factor to affect the quality of postgraduate education. Based on some existing problems about "double postgraduate tutors scheme" implementation process, This paper discusses implementation of "double postgraduate tutors scheme" from seven aspects, which includes strengthening "double postgraduate tutors scheme" management document, strengthening cooperation consciousness between school and enterprise, reforming teacher recruitment system, strengthening training of professional degree postgraduate tutors, arousing tutors' enthusiasm, strengthening cooperation mechanism and supervision of tutors from campus and outside school.
\end{abstract}

Keywords-professional degree; double tutorial system; school-enterprise cooperation

\section{INTRODUCTION}

Professional degree is parallel with academic degree, which is mainly to train high level qualified personnel. It has a specific occupation directivity. In 2009, China began to recruit full-time professional degree postgraduates. In order to meet the rapid development of professional degree education and explore the suitable training pattern. Ministry asks school to build a "double tutorial system".

Because professional degree postgraduates education research develops late, most universities use academic degree postgraduates training pattern to train professional degree postgraduates. Most tutors are academic tutors which are lack of practical experience. This training pattern is difficult to train the high-level qualified personnel. It is far from intention of developing professional degree education. In order to improve practical ability of professional degree postgraduates, universities must rely on off-campus professionals with rich practical experience. It has become an inevitable choice to off-campus tutors to implement “double tutorial system”[1,2,3].

This paper discusses implementation of "double postgraduate tutors scheme" from seven aspects, which includes strengthening "double postgraduate tutors scheme" management document, strengthening cooperation consciousness between school and enterprise, reforming teacher recruitment system, strengthening training of professional degree postgraduate tutors, arousing tutors' enthusiasm, strengthening cooperation mechanism and supervision of tutors from campus and outside school.

\section{PROBLEM OF "DOUBLE SUPERVISOR SYSTEM"}

"Double tutorial system" is to hire off-campus professionals with rich practical experience to join training of professional degree postgraduates. It can make up for the shortage of campus tutors's practical guiding , Unleash respective advantages and train qualified professional degree postgraduates.But in the process of concrete implemention, this scheme has many questions. It is difficult to exert the advantages of this system[4,5].

\section{A. Fake "Double Supervisor System"}

In order to complete Ministry's requirements about this system, universities are equipped with off-campus tutors.However, these tutors don't give postgraduates practical guidelines in the process of training. They are only "nominal mentors".

\section{B. Not Choose Suitable Tutors from Outside Universities}

Full-time professional degree postgraduates are fresh graduates who don't participate in the work and have very little contact with enterprise, it is very difficult for them to find high level tutors which is suitable for their own professional direction.The system must rely on universities to contact off-campus tutors, how to find a suitable tutor for postgraduates is one of the difficult problems which must be solved for universities.

\section{On- Campus Tutors are Lack of Practical Guidance}

On-campus tutors are engaged in theoretical research for a long time, most of them are lack of relevant professional experience. They lay stress on theory not application and are accustomed to use traditional training model to train professional degree postgraduates. Some on-campus tutors even think they are only responsible for training of the knowledge system and study guide about certain theories and ignore the training of practical ability of solving problems for professional degree postgraduates.

\section{Off-Campus Tutors are Lack of Enthusiasm}

Interpersonal relations of off-campus tutors belong to enterprise. They are as part-time postgraduate tutors at college and don't care too much about the work of college. Universities don't put forward more requirements and regulations on these tutors. Because universities give tutors 
too little allowance,it can't arouse their enthusiasm. Though postgraduates practice in the enterprise where their tutors work in the process of practice, universities don't have concrete measures to restrain tutor's duties. So it is a problem that how to arouse tutors' enthusiasm and improve their practical guide ability to postgraduates.

\section{E. Lack of Communication Between on-campus and off- campus tutors}

"Double tutorial system" need division and cooperation between on-campus and off-campus tutors, on-campus tutors are responsible for imparting theory, off-campus tutors teach extracurricular practice skills, only in this way can they unleash respective advantages. But the reality is that course topics of on-campus and off-campus tutors are not consistent, the research direction is different, and they are not familiar with each other and make very little communication, unable to achieve complementary advantages. Tutors lack of communication about training postgraduates and their responsibilities are unclear, and some tutors' responsibility are not strong, input energy is not enough, which greatly affect the quality of training.

\section{IMPLEMENTATION PLAN OF “DOUBLE TUTORIAL SYSTEM”}

\section{A. Draft Practical Training Scheme and Improve the " Double Tutorial System " Management Files}

Each graduate education in professional degree unit designs the full-time master's degree graduate training scheme under the guidance of the steering committee. Fully drawing lessons and absorbing the advanced experience of international and domestic professional degree postgraduate education. Actively exploring and innovating the full-time professional degree postgraduate training mode. Establish and improve the regulations of the " double tutorial system ", including appointment and management to on-campus and off-campus tutors, guidance, evaluation and reward to postgraduates, ,evaluation system and a series of documents. Clearing tutors' responsibility and duty in the process of fulltime postgraduate education in professional degree and forming an advisor team to adapt to the professional degree postgraduate education. Above mentioned is a key problem for carrying out the scheme.

\section{B. Strengthen the Awareness of Deep School-Enterprise Cooperation}

Universities can arrange some postgraduates to some enterprises which needs certain major's postgraduates to realise mutual benefits to enterprise and postgraduates.Hiring a cooperative enterprise's high-level technical personnels as off-campus tutors, on the one hand, making up the lack of practice teaching at colleges, highlight the professional and practical characteristics of professional degree, on the other hand, campus tutors profound theoretical basis research and enterprise technology practice to realize the technology innovation.Professional degree postgraduates can directly participate in the enterprise application in the process of training. Postgraduate who accept this training may go into the enterprise work after graduation.Such a " double tutorial system " training pattern will get support from enterprise and campus, and a lot of difficulties will be readily solved.Enterprises treat the training of postgraduates as their own work. Strengthening the effective management of the enterprise tutors and postgraduates has become inevitable. On this basis, enterprise and universities can make cooperation on subject research.

\section{Reform Scheme about Recruiting Tutors}

According to the characteristics of the professional degree postgraduate education, establishing a corresponding system to tutors evaluation[6]. Different from recruiting academic postgraduate tutors, recruiting professional degree postgraduates tutors do not treat paper and topic as standard, It should give priority to practical subject guidance ablity, scientific research level is second . Recruiting campus tutors not also pay attention to academic level, but also thinking their practical experience and ability to solve problems. Recruiting off-campus tutors mainly thinks about their ability to solve practical problems. General require senior professional titles, as far as possible to avoid hiring enterprise leadership who has rarely engaged in the professional and technical work, for those technicians with rich experience and sense of responsibility, even if they do not have the senior title ,we also should hire them as tutors.

In recent years, our university appoints senior technical staffs, which come from Inspur Cvicse or Shandong Computer Science Center, as computer technology professional master degree off-campus tutors. With the help of off-campus tutors which has rich practical experience, the practice and innovation ability of professional degree postgraduate has been greatly improved. At the same time On-Campus Tutors and off-campus tutors cooperate more closely, Such as cooperation with Inspur to declare a number of provincial and ministerial level special projects.

\section{Strengthen the Training for Professional Degree Postgraduate Tutors}

Professional degree postgraduate education treats training of practice ability as the center, we need to have an appropriate pattern, method and means for professional degree postgraduate education[7]. Therefore, colleges and universities must give new selection to professional degree postgraduate tutors about teaching idea, teaching methods and so on. Universities can invite domestic and overseas experts and scholars with rich professional degree postgraduate education and teaching experience to give lectures. Change traditional teaching method and use case teaching method and practical operation method which are suitable for professional postgraduate education,improve the practical ability of postgraduates. Select academic tutors who train professional degree postgraduates to enterprise for training and exercising, By participating in the concrete practice and obtaining the corresponding practical experience, improve level of postgraduate tutors about training professional degree postgraduates practical ability. 
In order to ensure the quality of postgraduate tutors, Dynamical auditing of tutor qualifications is necessary every three years in our university. Department of graduate examine project funds, respectively and the results, graduate teaching. If the result of dynamic audit is not qualified, the enrollment is stopped this year. If stopping enrollment of postgraduates for three years, cancel its master's tutor qualifications. The dynamic audit mobilize the enthusiasm, perfect our school master's degree graduate tutor management system and form a dynamic management mechanism of competition for master tutor.

\section{E. Inspire the Enthusiasm of on-campus and off-campus Tutors}

Most university school teachers with a sub-senior title can obtain postgraduate tutor qualifications, in order to build up a group of teachers with rich practical experience obtain the professional degree qualified tutors qualifications, and better guide professional degree postgraduates, We should not treat teacher's thesis topic as standard and pay more attention to teachers' practical experience and ability to solve practical problems. Make a group of teachers with rich practical experience promote senior professional titles and obtain professional degree tutors qualifications, enrich the school tutor team.

Improve the treatment of off-campus tutuors, the key of "double tutorial system" is to give full play to the function of the off-campus tutors and make up the lack of practical experience of campus tutors. We must motivate the enthusiasm of tutors from outside universities, improve their treatments, increase the intensity of subsidies on tutors. Only in this way, can we give play to the role of the practice guidance of experienced, and achieve goals to improve professional degree postgraduates' practice ability.

\section{F. Strengthen the Exchanges and Cooperation Mechanism of on-campus and off-campus tutors}

To perfect the "double tutorial system" we must strengthen communication of on-campus and off-campus tutors[8]. "Double tutorial system" give priority to oncampus tutors, and off-campus tutors are second. The campus tutors should actively communicate with offcampus tutors.Through communication, on-campus and offcampus tutors can make an individual training plan and implement individualized instruction for postgraduates. Through communication,making on-campus and off-campus tutors realize the complementary. It not only shows profound basic theories and advantages of strong scientific research ability of campus tutors, but also shows on-campus and offcampus tutors have rich practical experience and the characteristics of sovling actual problem ability.It can better understand with specialized degree graduate students' learning and practice.Further improvement measures are put forward based on these conditions, improving the ways and methods of the graduate education in professional degree, avoiding the basic theory teaching and practice skills training disconnects when guiding the professional degree postgraduates.

\section{G. Strengthen the Supervision of on-campus and off- campus Tutors}

"Double tutorial system" is a the university-enterprise joint training pattern, making effective supervision scheme is very necessary. Only let the school and the enterprise clear their respective responsibilities, effectively strengthen school-enterprise tutors cooperation " double tutorial system " play a positive role in postgraduate education in professional degree. Enterprise and school are on the basis of mutually beneficial cooperation , and they formulate corresponding supervision measures and incentive measures to own tutors, to ensure the quality of the implementation of the scheme.

Strict tutors appraisal system[9]. To motivate tutors to improve their own quality and ability to guide professional degree postgraduates .Universities must carry on the strict examination to the tutors, appraisal results directly linked to tutor's appointment, remuneration. Unqualified tutors in the assessment can cancel the postgraduates tutors qualification. Through the strict examination, enhance the tutor's responsibility and prompt the tutors actively perform their duties, train more high level talents.

\section{CONCLUSIONS}

With the adjustment of postgraduate education's structure, proportion of full-time professional degree postgraduates is more and more heavy. It will convey high level qualified personnel for the enterprise and provide the powerful safeguard for enterprise to change from manufacturing to innovation. Both school and the enterprise should seize the opportunity and make use of the construction opportunity to develop together. Universities can further cooperate with enterprises. Universities can also reserve talents for the high level development of enterprises and inject new vitality for the long-term development of enterprises. Only both school and enterprise have realized this point, the " double tutorial system " of full-time professional degree graduate training can be realized.

\section{ACKNOWLEDGMENT}

The research work was supported by the Innovation Project of Shandong Graduate Education under Grant No.SDYY12110 and SDYC14013.

\section{REFERENCES}

[1] Youdong Z,Zhonghui L,Yingli W. Study on Double Supervisor mechanism for Professional Master Degrees[J].Academic Degrees \& Graduate Education.3,pp14-17,2014.

[2] Hongfeng S.,Na C., The question and countermeasure on "Double Tutorial System"-- full-time professional degree graduate students as an example. Theory Research,18,pp201-202,2012.

[3] Hongkang Z., Double Tutorial System: a new mechanism for the cultivation of innovativePostgraduates.Jiangsu Higher Education,5,pp91-93,2006

[4] Jianbin S.Liang L.Yan S., Study on the effective operation of the functions of professional degree graduate Double Tutorial System.University Education,1,pp13-15,2015. 
[5] Lei Z.,Yuanquan C.,Professional degree graduate "Double Tutorial System" training mode analysis.Time Education,5,pp84,2012.

[6] Xingwen C.Pixi Z.,Bin M., Countermeasure Research on Construction of Double Tutors System of Full- time Master Professional Degree Postgraduate.Journal of Dalian Nationalities University,5(15),pp558-561,2013.

[7] Yuchen F.,Yanqin Z.,Shengrong G.,The exploration and practice of innovative talents cultivation of Double Tutorial System Applied IT.Computer Education,21,pp33-36,2008.
[8] Xiuqing L.,study on the implementation scheme of "Double Tutorial System” for full-time professional degree graduate. Education Teaching Forum,30,pp20-21,2012.

[9] He J.,xiangjun D.,Jinyong C.. Research and Practice of Innovative Personnel Training Mode for IT Postgraduates[A]. IWET 2012.pp439-442. 